\title{
Dislocation Creep of Olivine and Amphibole in Amphibole Peridotites from Åheim, Norway
}

\author{
Sejin Jung ${ }^{1}\left(\mathbb{D}\right.$, Takafumi Yamamoto ${ }^{2,+}$, Jun-ichi Ando ${ }^{2}$ and Haemyeong Jung ${ }^{1, *(D)}$ \\ 1 Tectonophysics Laboratory, School of Earth and Environmental Sciences, Seoul National University, \\ Seoul 08826, Korea; shazabi7@snu.ac.kr \\ 2 Department of Earth and Planetary Systems Science, Hiroshima University, \\ Higashi-Hiroshima 739-8526, Japan; takayamamoto@micron.com (T.Y.); jando@hiroshima-u.ac.jp (J.-i.A.) \\ * Correspondence: hjung@snu.ac.kr; Tel.: +82-2-880-6733 \\ $\dagger$ Present address: Yield Enhancement Group, Technology Development, Micron Memory Japan, G.K., \\ Higashi-Hiroshima 739-0198, Japan.
}

check for updates

Citation: Jung, S.; Yamamoto, T.; Ando, J.-i.; Jung, H. Dislocation Creep of Olivine and Amphibole in Amphibole Peridotites from Åheim, Norway. Minerals 2021, 11, 1018. https://doi.org/10.3390/min11091018

Academic Editors: Jacques Précigout, Cécile Prigent and Bjarne Almqvist

Received: 5 July 2021

Accepted: 15 September 2021

Published: 18 September 2021

Publisher's Note: MDPI stays neutral with regard to jurisdictional claims in published maps and institutional affiliations.

Copyright: (c) 2021 by the authors. Licensee MDPI, Basel, Switzerland. This article is an open access article distributed under the terms and conditions of the Creative Commons Attribution (CC BY) license (https:// creativecommons.org/licenses/by/ $4.0 /)$.

\begin{abstract}
Amphibole peridotite samples from Åheim, Norway, were analyzed to understand the deformation mechanism and microstructural evolution of olivine and amphibole through the Scandian Orogeny and subsequent exhumation process. Three Åheim amphibole peridotite samples were selected for detailed microstructural analysis. The Åheim amphibole peridotites exhibit porphyroclastic texture, abundant subgrain boundaries in olivine, and the evidence of localized shear deformation in the tremolite-rich layer. Two different types of olivine lattice preferred orientations (LPOs) were observed: B- and A-type LPOs. Electron backscatter diffraction (EBSD) Mapping and transmission electron microscopy (TEM) observations revealed that most subgrain boundaries in olivine consist of dislocations with a (001)[100] slip system. The subgrain boundaries in olivine May have resulted from the deformation of olivine with moderate water content. In addition, TEM observations using a thickness-fringe method showed that the free dislocations of olivine with the (010)[100] slip system were dominant in the peridotites. Our data suggest that the subgrain boundaries and free dislocations in olivine represent a product of later-stage deformation associated with the exhumation process. EBSD Mapping of the tremolite-rich layer revealed intracrystalline plasticity in amphibole, which can be interpreted as the activation of the (100)[001] slip system.
\end{abstract}

Keywords: deformation mechanism; Åheim amphibole peridotite; shear localization; olivine; amphibole; lattice preferred orientation; subgrain boundary; dislocation; slip system

\section{Introduction}

The relationship between the lattice preferred orientation (LPO) of olivine and the active slip system of dislocations is relatively well understood through theoretical and experimental studies [1-3]. Crystal deformation associated with dislocation creep is considered an important mechanism for LPO formation, which is heavily influenced by the easiest slip system [1]. Various theoretical models, such as the Taylor-Bishop-Hill model [4,5] and the self-consistent approach [6,7], have been developed to calculate the formation of LPO by dislocation glide. The deformation mechanisms and rheology of olivine have been the key to understanding the kinematics and seismic anisotropy of the upper Mantle [8,9]. In previous experimental studies of olivine aggregates, researchers have reported the development of various types of olivine LPOs, depending on the physicochemical conditions during its deformation [3,10-14]. For example, the A-type LPO of olivine is characterized by the [100] axes aligned subparallel to the shear direction, and the [010] axes aligned normal to the shear plane. The results of experimental studies have shown that the A-type LPO of olivine develops under conditions of low stress and low water content $[3,10]$. In the case of the B-type LPO of olivine, the [001] axes are aligned subparallel to the shear direction and the [010] axes are aligned normal to the shear plane. The B-type LPO of 
olivine develops under high water content and high stress conditions $[3,10]$. In addition, it has been reported that the B-type LPO of olivine can result from grain-size-sensitive creep such as diffusion creep and/or dislocation-accommodated grain boundary sliding (DisGBS) [15-17]. The close relationship between the LPO of olivine and the dominant dislocation slip system has been reported in a number of experimental studies [3,18,19]; however, there are only a few actual comparisons of the LPO and slip system of olivine in naturally deformed peridotite specimens [20,21].

Amphibole is one of the Major minerals in the middle to lower crust and a common hydrous mineral in Mantle rocks [22-25]. Because amphibole is elastically highly anisotropic and generally exhibits a strong LPO, the LPO of amphibole can have a significant influence on the seismic anisotropy of the lower crust [26-32]. The plastic deformation of amphibole by dislocation glide has been reported in both naturally deformed amphiboles and experimental research [27,33-35]. The LPO of amphibole can be produced by a variety of deformation mechanisms, such as rigid body rotation [29,36,37], cataclastic flow [26,28], diffusional creep (dissolution-precipitation creep) [28,38,39], and dislocation creep [27,29]. However, studies of the relationship between the LPO of amphibole and the activated slip system of amphibole are still very limited [27].

Åheim amphibole peridotites represent lithospheric Mantle inserted into the crustal rock during Scandian eduction [40]. Some of the Åheim amphibole peridotite samples showed signs of localized shear deformation in the form of a tremolite-rich layer [41]. A recent study of the microstructure of the Åheim amphibole peridotite samples focused on the LPO and fabric transition of the olivine and the LPO of amphibole [41]. Åheim amphibole peridotites showed evidence of multiple stages of deformation during the Scandian Orogeny and its subsequent exhumation [41]. The coarse olivine grains and olivines in the tremolite-poor layer showed an A-type olivine LPO, which corresponds to the initial stage of deformation. On the other hand, recrystallized-fine olivine grains and olivines in the tremolite-rich layer showed a B-type olivine LPO, which represents the later-stage deformation associated with the exhumation process. The presence of abundant hydrous minerals and hydrous inclusions in olivine, as well as the high water content of olivine, suggests that the fabric transition of olivine from the A-type to B-type LPO resulted from the deformation in a water-rich condition during the exhumation process [41].

In this study, detailed microstructural studies were performed on three representative amphibole peridotite samples from Åheim, Norway, as the continuation of a previous study [41]. We analyzed the dislocation structures and dominant slip systems of both olivine and amphibole to relate the dominant slip systems to different natural deformation conditions.

\section{Geological Setting and Sample Description}

The Western Gneiss Region (WGR) in Norway is predominantly composed of gneissic rocks located between Bergen and Trondheim [42-44]. It represents the crustal root zone of the Caledonian mountain belt [42-44], which originated during the continent-continent collision between Laurentia and Baltica in the early Paleozoic [45-47]. The Scandian Orogenic event was the final stage of this orogenic process and resulted in a series of high-pressure to ultra-high pressure (HP to UHP) metamorphism in the WGR. The WGR in western Norway is mostly composed of orthogneisses and paragneisses with several emplaced peridotite or eclogite bodies (Figure 1). The proterozoic protolith of 1700-1600 Ma is overlain by continental and oceanic allochthons $[43,44]$. The Baltica-Laurentia collision from $\sim 425$ to 400 Ma resulted in HP to UHP metamorphism at pressures and temperatures between 1.8-3.6 GPa and $600-800{ }^{\circ} \mathrm{C}$, respectively [48,49]. After this collision, the WGR was exhumed to a shallow crustal level of $15-20 \mathrm{~km}$ and underwent amphibolite facies retrogression at pressures of $0.5-1.5 \mathrm{GPa}$ and temperatures of $650-850{ }^{\circ} \mathrm{C}$ from $\sim 400$ to $\sim 385 \mathrm{Ma}[44,50]$. Many orogenic peridotite bodies and lenses were emplaced into the crustal rocks of the WGR during orogenic events or subsequent exhumation, including garnet lherzolite and dunite bodies in the Nordfjord-Stadlandet UHP domains [40,51,52]. During 
the exhumation process, some of the garnet peridotites were infiltrated by aqueous fluids and experienced multiple stages of deformation and associated recrystallization in the granulite facies (olivine + orthopyroxene + clinopyroxene + spinel) and amphibolite facies (olivine + orthopyroxene + amphibole + chlorite) [51,53-55].

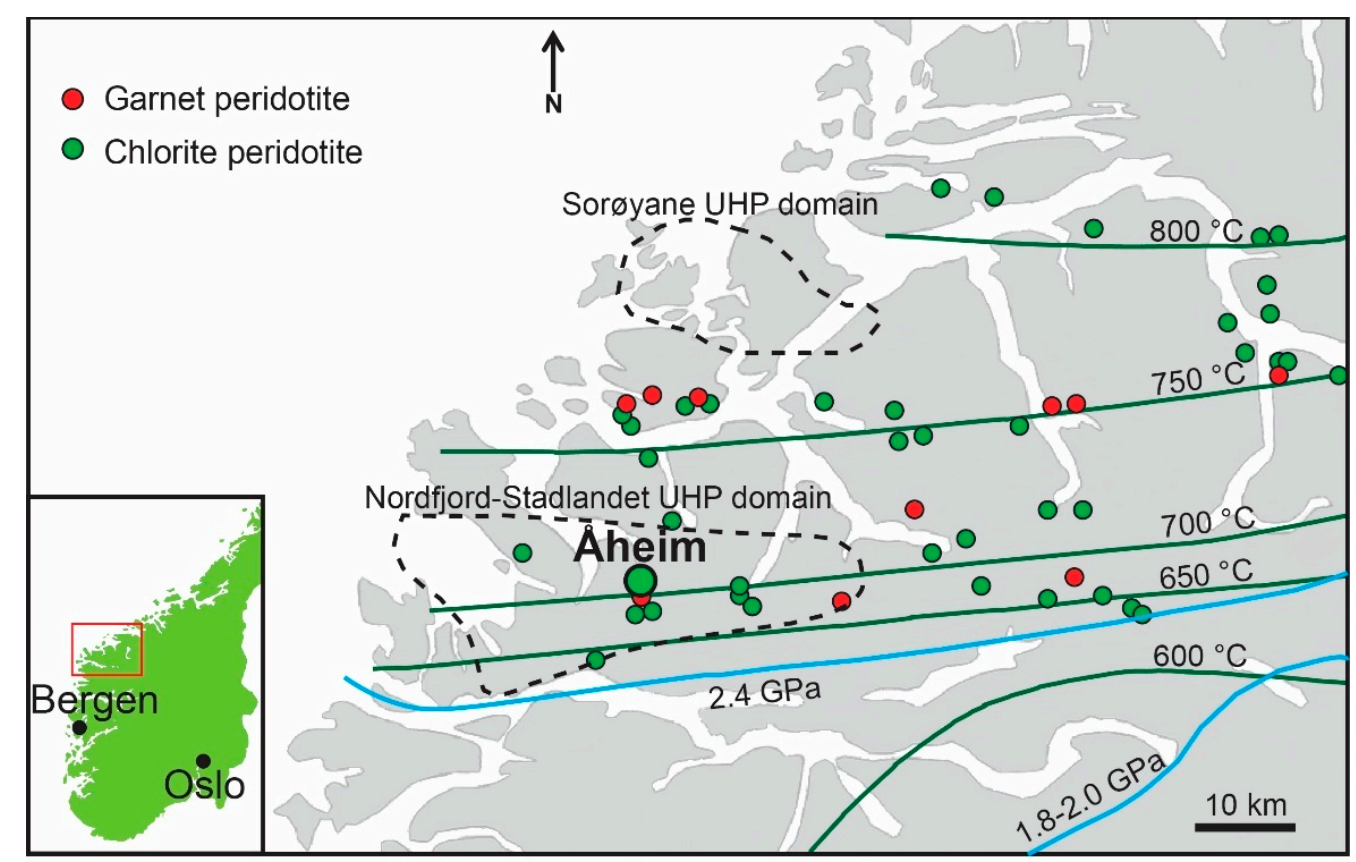

Figure 1. Distribution of peridotite bodies in the Western Gneiss Region, SW Norway (modified from Austrheim [42], Brueckner et al. [40], Jung et al. [41], Root et al. [50], and Wang et al. [52]). Magnified view of the red rectangle area, SW Norway. Samples selected for this study are from the Gusdal quarry in the Åheim region (larger green circle). Green lines indicate the approximate peak metamorphic temperature [56], and light blue lines Mark the eclogite isobar of 1.8-2.0 GPa and 2.4 GPa [44,52]. Locations of chlorite and garnet peridotite bodies are Marked with green and red circles, respectively. Two ultra-high pressure (UHP) domains, Nordfjord-Stadlandet and Sorøyane, are contoured with black dashed lines.

Three representative amphibole peridotite samples $(443,447$, and 448$)$ collected from Åheim, Western Norway (Figure 1), were selected for a more detailed microstructural study. Sample 447 was selected as a representative sample showing B-type olivine LPO. Sample 448 was selected as representative of A- and B-type olivine LPOs; coarse olivine grains in sample 448 showed A-type LPO of olivine and recrystallized-fine olivine grains in sample 448 showed B-type LPO of olivine [41]. Sample 443 was selected in order to study the microstructure of tremolite in the tremolite-rich layer [41]. Most samples show a porphyroclastic texture that predominantly consist of olivine $(>90 \%)$ with a minor amount of chlorite, orthopyroxene, amphibole (tremolite), biotite, and spinel (Figure 2A-E; Supplementary Table S1). Sample 443 shows a locally tremolite-rich layer with an approximately $42 \%$ modal composition of tremolite (Figure 2E,F; see Supplementary Table S1 for modal proportions of samples). The foliation of the samples is well defined by a compositional layering of olivine, amphibole, and chlorite. The elongated olivine grains are also well aligned along the foliation (Figure 2A,B). Sample 447 (Figure 2A) is relatively more recrystallized than sample 448 (Figure 2B). The average grain size of the sample 447 is $0.5 \mathrm{~mm}$ [41]. Sample 448 shows a clear porphyroclastic texture (Figure 2B); the average grain size of the fine grains and the coarse grains in sample 448 are $0.35 \mathrm{~mm}$ and $1.2 \mathrm{~mm}$, respectively [41]. Olivine porphyroclasts have curvy grain boundaries (Figure 2B,D). Smaller recrystallized olivine grains often have straight grain boundaries and triple junctions (Figure 2A). Undulose extinction and subgrain boundaries are common in all samples (Figure 2C,D). The tremolite-rich layer shows a strong shape preferred orientation (SPO) of tremolite parallel 
to the foliation (Figure 2E). The grain sizes of tremolite and olivine in the tremolite-rich layer are smaller than those in the tremolite-poor layer (Figure 2E) [41].
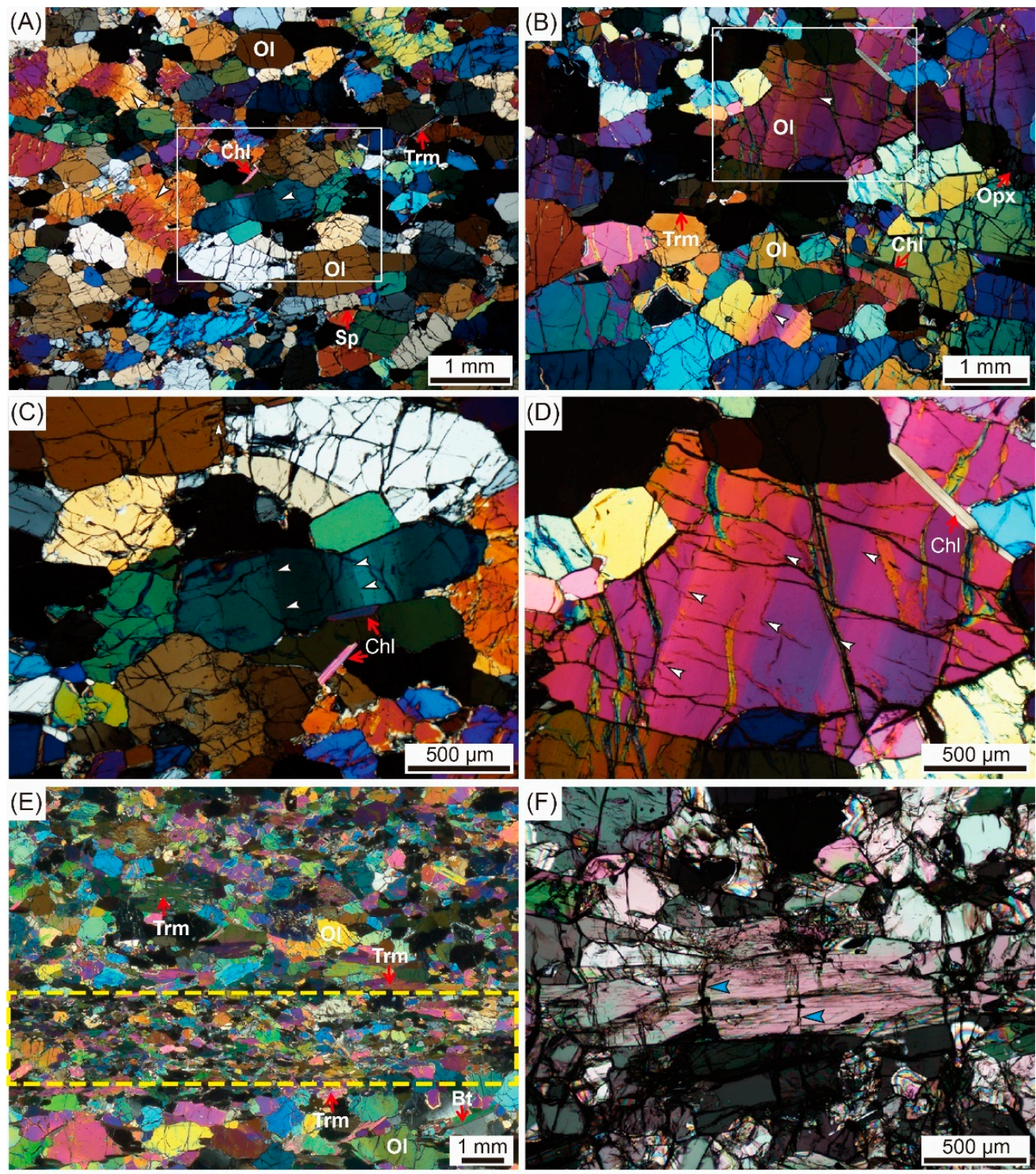

Figure 2. Optical photomicrographs of samples in transmitted, cross-polarized light. (A,B) Representative wide-view images of samples 447 (A) and 448 (B). Olivine grains are well elongated along the foliation. White arrow heads Mark the clear subgrain boundaries in olivine. White boxes Mark the location of the areas shown in Figure 2C,D. (C,D) Enlarged image of the olivine crystals showing clear subgrain boundaries for sample 447 (C) and sample 448 (D). White arrow heads indicate subgrain boundaries in olivine. (E) Representative wide-view images of samples 443. Tremolite-rich layer is Marked by yellow dashed lines. (F) Magnified view of tremolite in sample 443. Blue arrows Mark the fractures in the tremolite. Abbreviations: Ol: olivine Trm: tremolite, OPx: orthopyroxene, Chl: chlorite, Sp: spinel, BT: biotite.

\section{Experimental Methods}

\subsection{EBSD Data Acquisition and Processing}

Electron backscatter diffraction (EBSD) Mapping was performed to identify evidence of intracrystalline plasticity in olivine and amphibole. Foliation of the samples was determined by compositional layering of well-aligned olivine, chlorite, and tremolite. Lineation was determined by examining the shape-preferred orientation of elongated olivines in the foliation using the projection-function method [57]. Thin sections for the EBSD analysis 
were prepared in the x-z plane of each Åheim amphibole peridotite (x: lineation, z: normal to foliation). EBSD data were collected using a scanning electron microscope (SEM, JEOL, Akishima, Japan) (JEOL JSM-6380 and JSM-7100F) equipped with an EBSD detector (Symmetry from Oxford Instruments, Abingdon, UK) housed at the School of Earth and Environmental Sciences at the Seoul National University. The collected EBSD data were processed using HKL Channel 5 software (Version 5.12.74.0, Oxford Instruments, Abindon, UK) and AZtec software (Version 1.1, Oxford Instruments, Abindon, UK).

EBSD Mapping of the olivine was performed using a JEOL JSM-6380 SEM with a tilt angle of $70^{\circ}$ and an acceleration voltage of $20 \mathrm{kV}$. A total of 20 olivine grains exhibiting well-defined subgrain boundaries were analyzed for each sample in order to gather the rotation axes with a misorientation angle of $2-10^{\circ}$. The step size for the EBSD Mapping was in the range of 3-8 $\mu \mathrm{m}$, depending on the size of the analyzed grain. For olivine grains with subgrain boundaries, EBSD Mapping along the olivine subgrain boundaries was performed to determine the dominant slip system of olivine dislocations in the subgrain walls. The rotation axes of olivine across the subgrain boundaries can be used to constrain the slip system [58-60]. The slip direction and slip plane of the subgrain boundary can be specified by considering the geometrical relationships between the rotation axes and subgrain boundary of each olivine single grain [58-60]. This method has been applied to define the activated slip systems of porphyroclastic natural peridotite samples from various localities [16,21,61-66].

Crystallographic orientation Maps were constructed for sample 443 to analyze the amphibole microstructure. EBSD data were collected using a JEOL JSM-7100F SEM with a tilt angle of $70^{\circ}$, acceleration voltage of $15 \mathrm{kV}$, and step size of $5 \mu \mathrm{m}$. In addition, detailed EBSD Mapping with a step size of $0.5 \mu \mathrm{m}$ was conducted to identify the internal misorientation of the tremolite. The collected EBSD data were cleaned using AZtec software. Very small grains with a grain size of 5 pixel were removed, and non-indexed pixels with a minimum of five identical neighbors were replaced by the average orientation of the five identical neighboring pixels. Using the EBSD data, crystallographic orientation Maps were processed using the Channel 5 software and AZtecCrystal software. Grain reconstruction was performed with a critical misorientation angle of $10^{\circ}$. To Map the internal misorientation inside tremolite, the kernel average misorientation (KAM) analysis, grain orientation spread (GOS), and grain reference orientation deviation (GROD) analysis from the mean orientation were used [67-69]. The KAM is the average misorientation between a pixel and its neighbors. The GOS is the average of the misorientation angles between each pixel in the grain and the grain mean orientation [69]. This approach leads to assigning the same GOS value to every pixel in the grain. The GROD is based on the deviation in the orientation of a measured pixel from the reference orientation of the grain to which the pixel belongs [69]. In this study, the reference orientation of the grain was chosen as the mean orientation of the considered grain.

\subsection{Observation of Dislocation Microstructures of Olivine Using TEM}

The slip system of the free dislocations in olivine was determined using transmission electron microscopy (TEM, JEOL, Akishima, Japan). Electron transparent thin foil specimens were prepared from thin sections parallel to the $x-z$ plane of the Åheim peridotite samples. The x-z plane thin sections were mechanically thinned to approximately $30 \mu \mathrm{m}$ and optically polished with colloidal silica on both sides. Electron-transparent areas of the foil were obtained by ion thinning with an argon ion beam accelerated at $6 \mathrm{kV}$ and $0.6 \mathrm{Ma}$ using a precision ion polishing system (Gatan). Dislocation microstructures in olivine were observed using a JEOL JEM-2010 TEM at the Natural Science Center for Basic Research and Development (N-BARD) of Hiroshima University, using an accelerating voltage of $200 \mathrm{kV}$. The dislocation density $(\rho)$ of the olivine was calculated from the TEM images by counting the number of free dislocations $(\mathrm{N})$ in the measured area $(\mathrm{S})$ [70]:

$$
\rho=\mathrm{N} / \mathrm{S} \text {. }
$$


To identify the Burgers vector and slip system of dislocation, the thickness-fringe method [71,72] was applied to the weak-beam dark-field (WBDF) TEM image. The thickness fringe method defines the Burgers vector of dislocations by counting the number of terminating thickness fringes at the extremity of dislocation from the WBDF TEM images. The number of terminating thickness fringes $n$ is then applied to the relation:

$$
\mathbf{g} \cdot \mathbf{b}=n
$$

where $\mathbf{g}$ represents the diffraction vector and $\mathbf{b}$ represents the Burgers vector. Using the Burgers vector, a dislocation can be identified by determining the $n$ of the three different $\mathbf{g}$ for the same dislocation. With this method, the exact value of $\mathbf{g} \cdot \mathbf{b}=n$ can be obtained from the TEM image; thus, the Burgers vector of the dislocation can be more precisely determined than the conventional invisibility criterion, $\mathbf{g} \cdot \mathbf{b}=0$. The slip system of the dislocation can be defined by the relationship between the Burgers vector and the dislocation direction vector.

\section{Results}

\subsection{Dominant Slip System of Olivine Determined by EBSD Mapping along Subgrain Boundaries}

The EBSD Mapping results along olivine subgrain boundaries are illustrated in Figure 3 and summarized in Supplementary Table S2. For most olivine subgrain boundaries, subgrain walls are subparallel to the (100) plane with rotation axes parallel to the [010] axes (Figure 3A), indicating the activation of the (001)[100] slip system of olivine [58]. Fifteen of the 20 subgrain boundaries were identified as (001)[100] subgrain boundaries in both 447 and 448 samples (Figure 3B; Supplementary Table S2). Minor slip systems of (010)[100], \{0k1\}[100], (100)[001], and (010)[001] were also identified (Figure 2B; Supplementary Figure S1; Supplementary Table S2).

\subsection{Microstructure of Amphibole Analyzed by the EBSD Mapping}

The phase Map, inverse pole Figure Map, GOS Map, and pole Figure of tremolite in the tremolite-rich layer of sample 443 are illustrated in Figure 4. The phase Map and pole figure of tremolite showed strong SPO and LPO of tremolite (Figure 4A,B,D). Tremolite grains are elongated parallel/subparallel to the foliation, and the [100] axes of tremolite are aligned subnormal to the foliation (Figure 4D). The GOS Map of tremolite shows several tremolite grains with high GOS values (Figure 4C). The LPO of tremolite obtained by EBSD Mapping is almost identical to the Manually indexed result obtained from a previous study [41]; the [001] axes and \{010\} poles of tremolite formed a girdle distribution parallel to the foliation with a high concentration of [001] axes clustered subparallel to the lineation, and [100] axes of tremolite aligned subnormal to the foliation (Figure 4D). The misorientation axes of tremolite with intracrystalline misorientation angles ranging from $2^{\circ}$ to $10^{\circ}$ are strongly concentrated along the [001] and [010] directions (Figure 4E). 
(A)
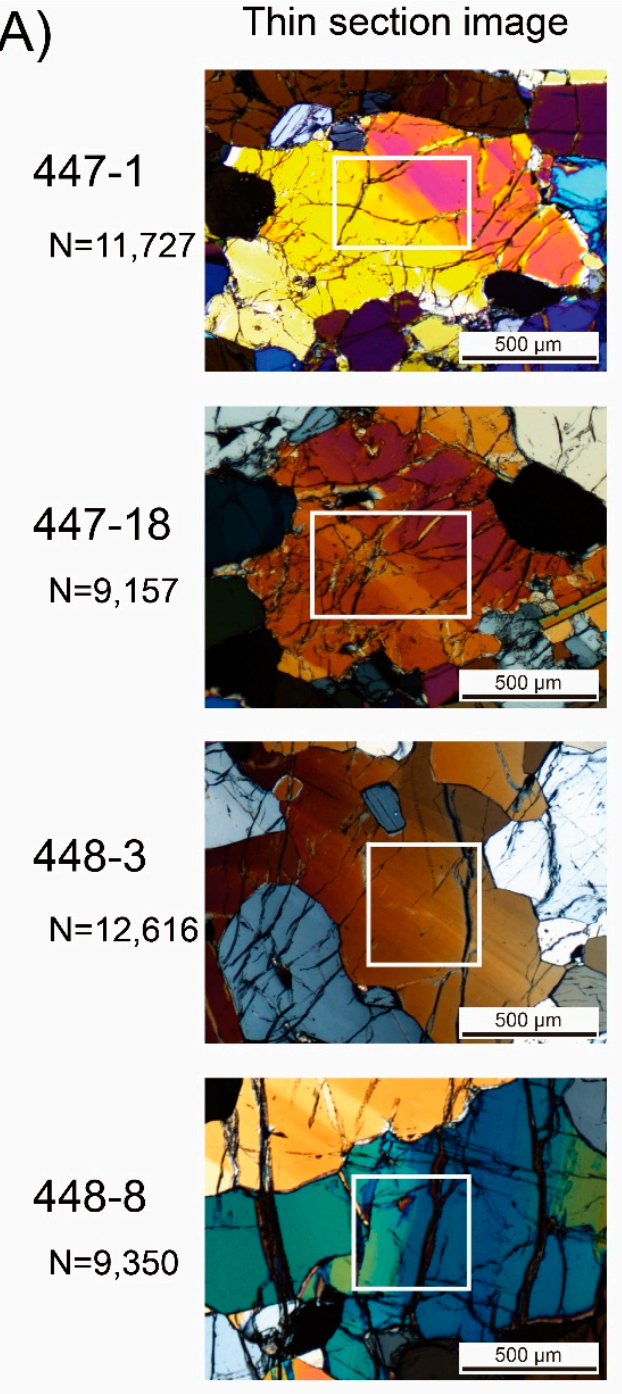

(B)

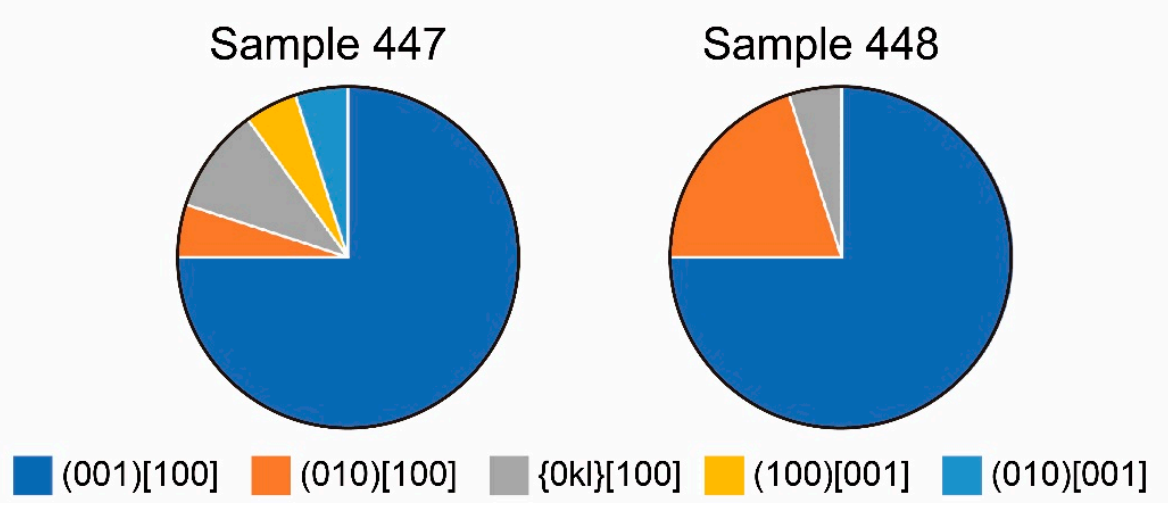

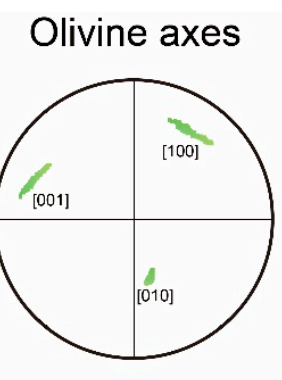

Rotation axis
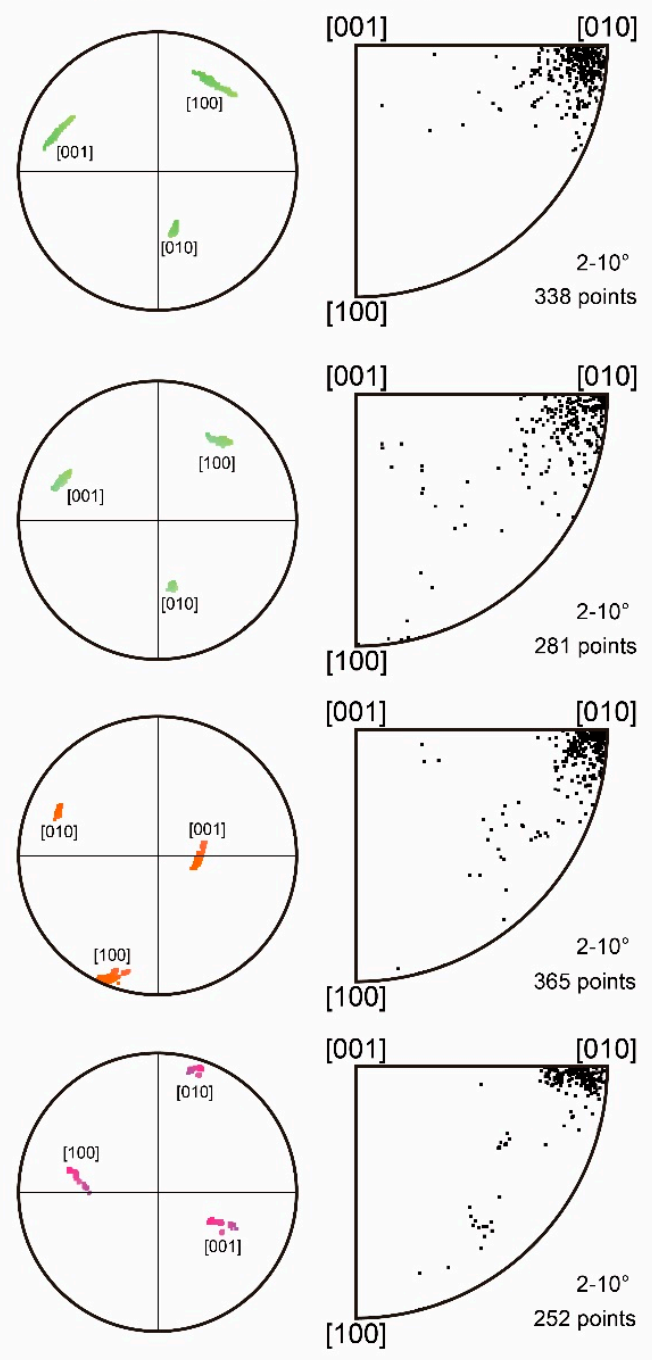

Figure 3. Identification of olivine slip system from olivine subgrain boundaries. (A) Microphotographs of samples 447 and 448 and the associated EBSD Mapping across olivine subgrain boundaries. The (001)[100] slip system was identified from all four olivine subgrain boundaries. White rectangles in the microphotographs constitute the actual EBSD Mapping area. The [100], [010], and [001] olivine crystallographic axes are plotted in the lower hemisphere of the stereonet. The rotational axis distribution with misorientation angles of $2-10^{\circ}$ is plotted in the inverse pole Figure. $\mathrm{N}$ is the number of data points for each EBSD Mapping. (B) Pie chart illustrating the different slip systems determined by EBSD Mapping along olivine subgrain boundaries (See Supplementary Figure S1). 
(A) Phase map
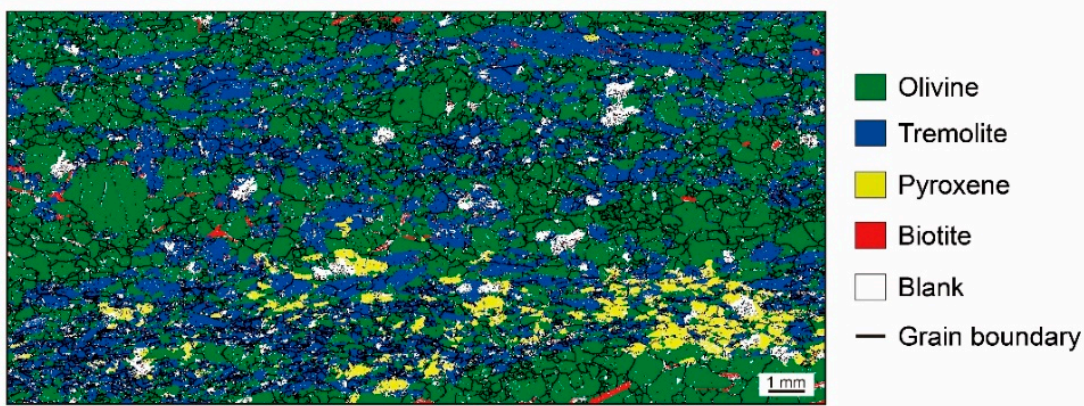

(B)

$\mathrm{Y}$ direction IPF coloring orientation map for tremolite

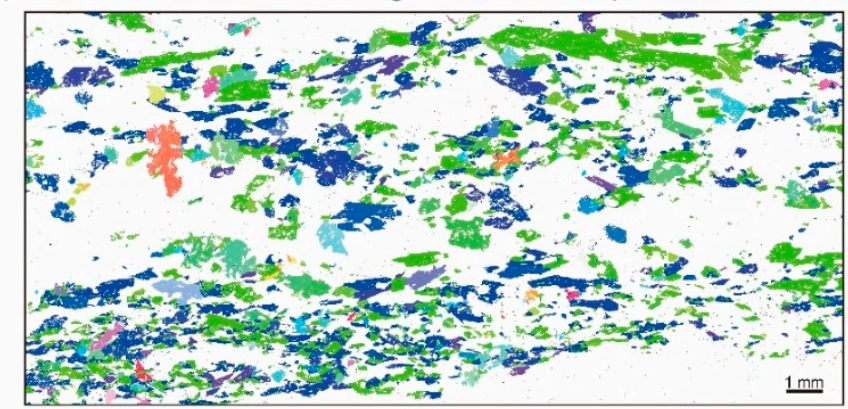

IPF colorcode

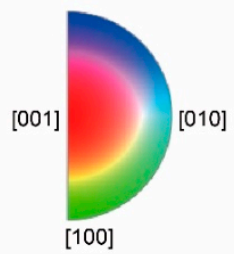

(C)

GOS map for tremolite

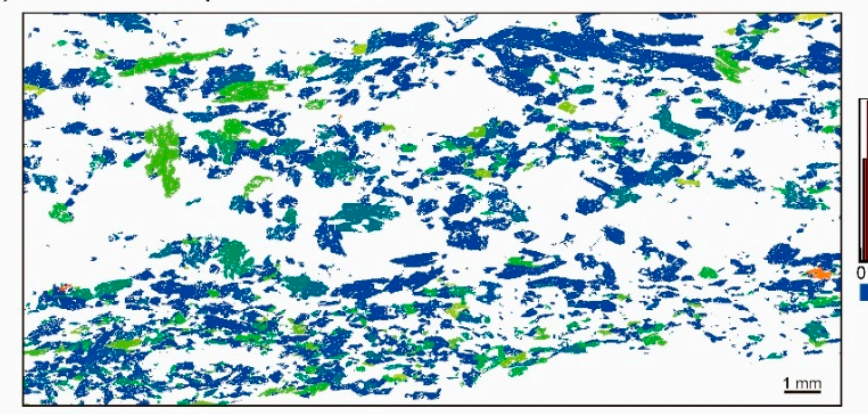

(D)

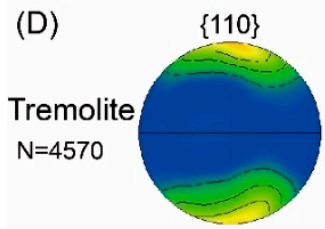

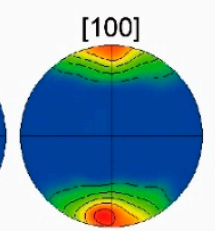
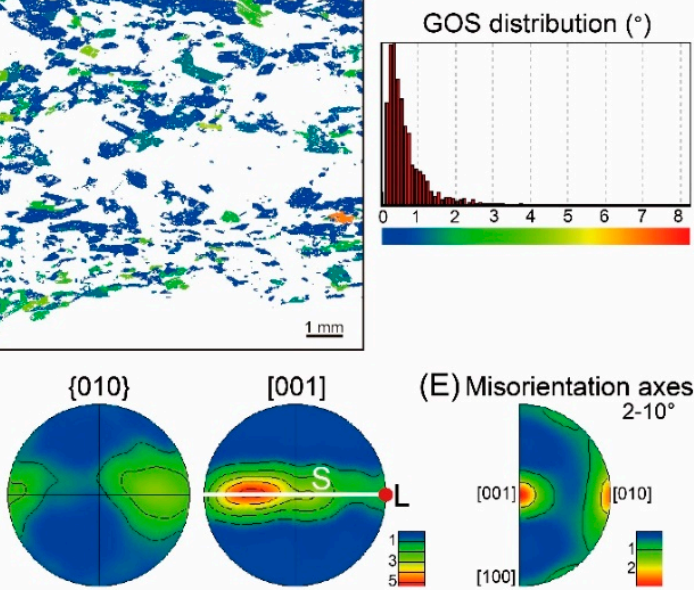

(E) Misorientation axes

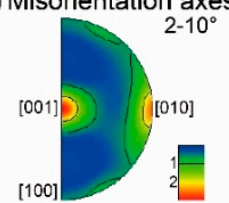

Figure 4. EBSD Maps (A-C) with associated pole Figure (D) and misorientation axis distribution (E) of the tremolite-rich layer from sample 443. (A) Phase Map of the tremolite-rich layer. (B) Orientation Map of tremolite using inverse pole Figure (IPF) color key (Y-axis, short axis of the Map). (C) Grain orientation spread (GOS) Map and GOS distribution histogram of tremolite. (D) Pole Figure of tremolite presented as one point per grain in the lower hemisphere using equal-area projection. "N" represents the number of analyzed grains. The white line (S) Marks the foliation, and the red dot (L) represents the lineation. (E) The misorientation axes distributions of tremolite are plotted in the inverse pole Figure. A half-scatter width of $20^{\circ}$ was used. The color-coding indicates the density of data points. The numbers in the legend correspond to multiples of uniform distribution.

The misorientation profiles within tremolite in the tremolite-rich layer of sample 443 are illustrated in Figure 5. Both the KAM Maps and the GROD Maps indicate the presence of intracrystalline misorientations in the tremolites (Figure 5). Several subgrain boundaries with a misorientation of $\sim 2^{\circ}$ (marked by white arrows in Figure 5) were identified from both the KAM Maps and the GROD Maps in tremolite without any cracks or fractures (Figure 5). In addition, some internal misorientations in the tremolites were identified as being associated with cracks or fractures (yellow arrows in Figure 5). 


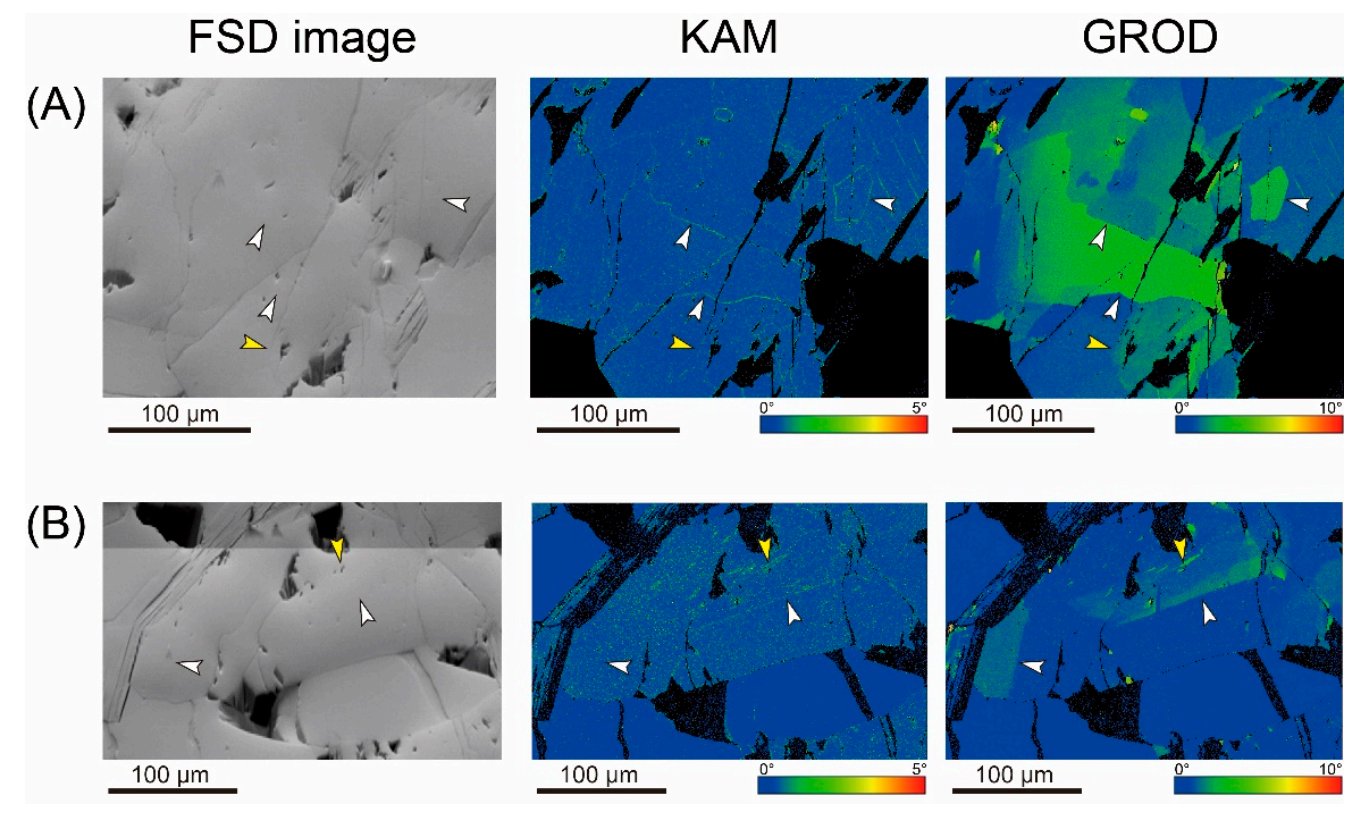

Figure 5. Internal misorientation Maps in tremolite grains from the tremolite-rich layer of sample 443. Forward scatter detector (FSD) image, kernel average misorientation (KAM) Map, and grain reference orientation deviation (GROD) Map are illustrated for two areas (A,B). The KAM ranges from $0^{\circ}$ to $5^{\circ}$, and the GROD ranges from $0^{\circ}$ to $10^{\circ}$. White arrows Mark the location of potential subgrain boundaries in tremolite grains. Yellow arrows Mark the intracrystalline misorientation associated with a crack or fracture.

\subsection{Olivine Slip Systems Determined by TEM Observation}

Representative analyses of the thickness fringe method for samples 447 and 448 are illustrated in Figure 6 and Figure 7, respectively. The results of these analyses are summarized in Supplementary Table S3. The average dislocation densities of samples 447 and 448 were $2.3 \times 107 \mathrm{~cm}^{-2}$ and $8.4 \times 106 \mathrm{~cm}^{-2}$, respectively. The Burgers vectors and slip systems of the observed olivine dislocations are summarized in Table 1. TEM observations revealed that both samples (447 and 448) demonstrated a dominant [100] edge dislocation on the (010) slip plane (Table 1). Examples of (010)[100] dislocations are illustrated in Figure 6A-C for sample 447 and in Figure 7A-C for sample 448. The same dislocations in different diffraction vectors are shown in Figure 6A-C. The number of terminating thickness fringes for each WBDF image is +2 in Figure $6 \mathrm{~A}(\mathrm{~g}=211),+1$ in Figure $6 \mathrm{~B}(\mathbf{g}=122)$, and +1 in Figure $6 \mathrm{C}(\mathbf{g}=112)$. The dislocation is parallel to the olivine [001] axes, its Burgers vector is [100], and its slip system is (010)[100] (Supplementary Table S3). As shown in Figure 7A-C, the number of terminating thickness fringes for each WBDF image was +1 in Figure 7A $(\mathbf{g}=131), 0$ in Figure 7B $(\mathbf{g}=004)$, and +1 in Figure 7C ( $\mathrm{g}=140)$; therefore, the Burgers vector of this dislocation is also [100] and the slip system is (010)[100] (Supplementary Table S3). A minor number of (010)[001] (Figures 6D-F and 7D-F) and (001)[100] (Figures 6G-I and 7G-I) dislocations were also observed in the same sample (Table 1; Supplementary Table S3). 

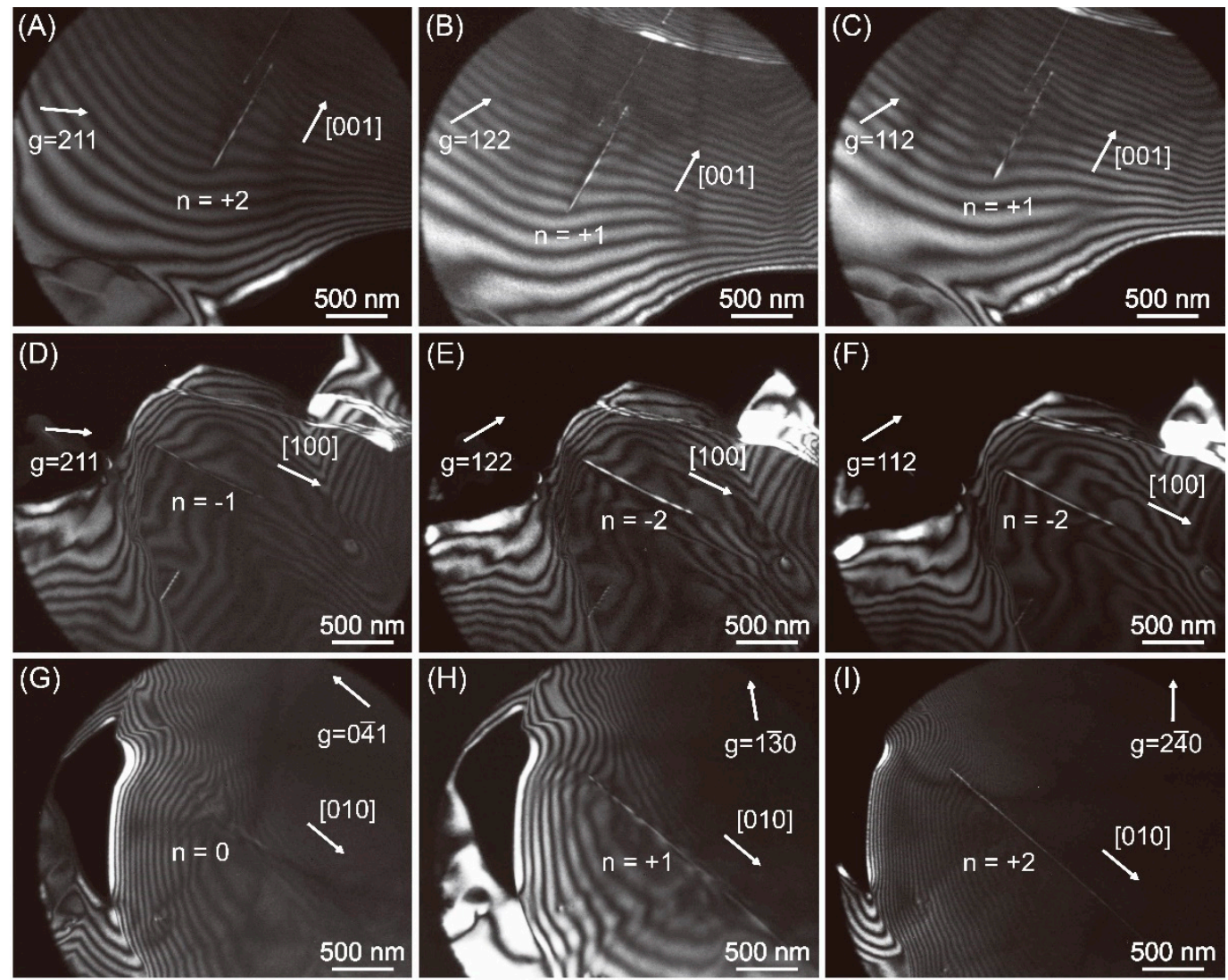

Figure 6. Representative weak-beam dark-field images showing the dislocation microstructure of olivine in three different locations from sample 447. The diffraction vectors for each image are noted as $\mathrm{g}$. The white arrow and $\mathrm{n}$ value indicate the number of the terminating thickness fringes for each image. (A-C) WBDF images of the same location with three different diffraction vectors: $\mathbf{g}=211$ in (A), $\mathbf{g}=122$ in (B), and $\mathbf{g}=112$ in (C). (D-F) WBDF images of a second location/site with three different diffraction vectors: $\mathbf{g}=211$ in (D), $\mathbf{g}=122$ in (E), and $\mathbf{g}=112$ in (F). (G-I) WBDF images of a third location / site with three different diffraction vectors: $\mathbf{g}=04 \dot{4} 1$ in $(\mathbf{G}), \mathbf{g}=130$ in $(\mathbf{H})$, and $\mathbf{g}=240$ in (I).

Table 1. Summary of olivine slip systems determined by the thickness fringe method in samples 447 and 448 .

\begin{tabular}{|c|c|c|c|c|c|c|}
\hline \multirow{2}{*}{ Sample } & \multirow{2}{*}{ Burgers Vector } & \multirow{2}{*}{ Slip System } & \multicolumn{4}{|c|}{ Number of Identified Dislocations } \\
\hline & & & Foil-1 & Foil-2 & Foil-3 & Sum \\
\hline \multirow{4}{*}{447} & \multirow{3}{*}{ [100] } & $(010)[100]$ & 5 & 7 & 0 & 12 \\
\hline & & (001)[100] & 0 & 0 & 7 & 7 \\
\hline & & Screw dislocation & 0 & 0 & 1 & 1 \\
\hline & [001] & $(010)[001]$ & 0 & 3 & 0 & 3 \\
\hline \multirow{4}{*}{448} & \multirow{3}{*}{ [100] } & $(010)[100]$ & 5 & 6 & 0 & 11 \\
\hline & & (001)[100] & 0 & 0 & 4 & 4 \\
\hline & & Screw dislocation & 0 & 0 & 1 & 1 \\
\hline & [001] & $(010)[001]$ & 2 & 0 & 1 & 3 \\
\hline
\end{tabular}



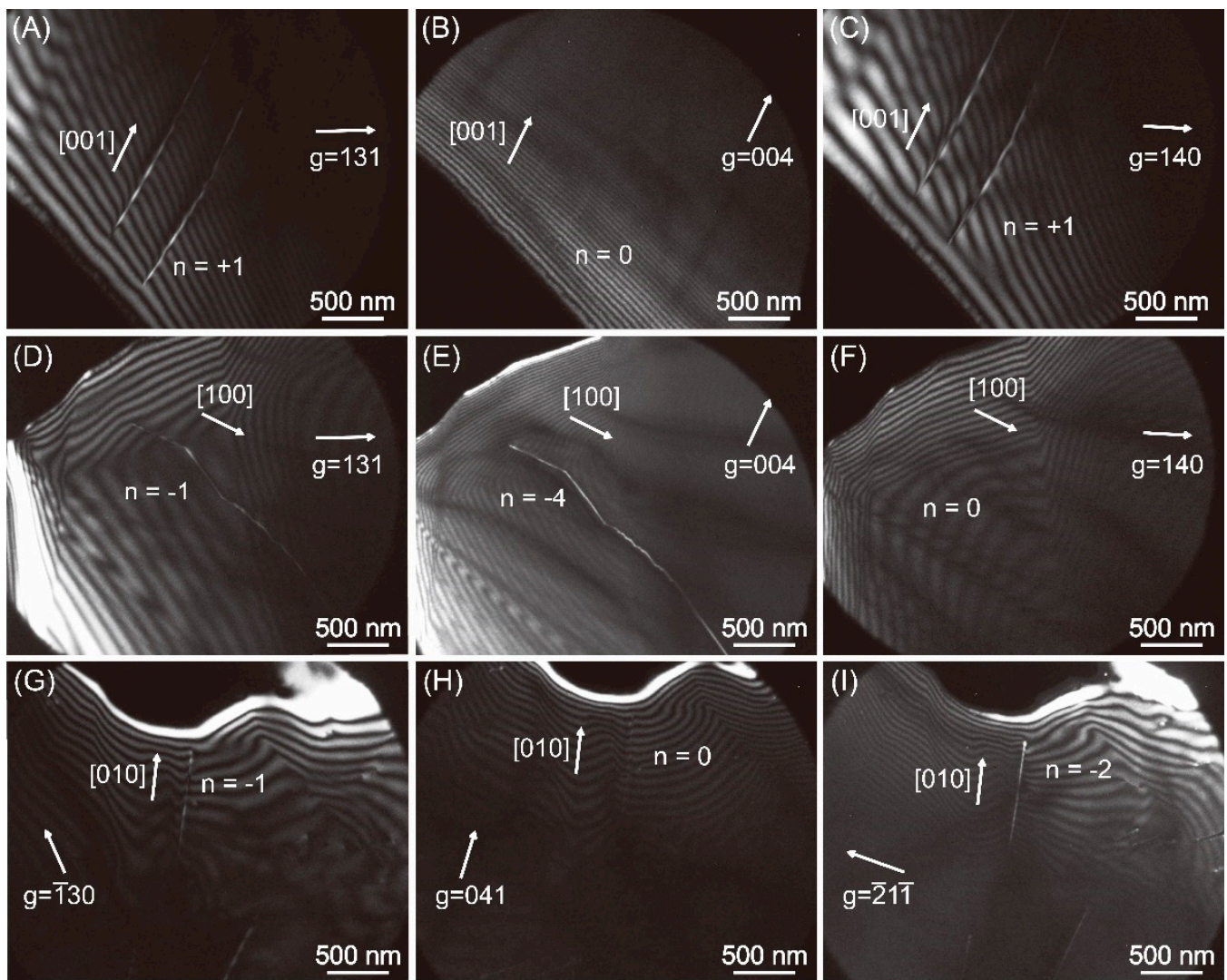

Figure 7. Representative weak-beam dark-field images showing the dislocation microstructure of olivine in three different locations from sample 448. The diffraction vectors for each image are denoted as $\mathrm{g}$. The white arrow and $\mathrm{n}$ value indicate the number of the terminating thickness fringes for each image. (A-C) WBDF images of the same location with different three diffraction vectors: $\mathbf{g}=131$ in (A), $\mathbf{g}=004$ in (B), and $\mathbf{g}=140$ in (C). (D-F) WBDF images of a second location/site with three different diffraction vectors: $\mathbf{g}=131$ in (D), $\mathbf{g}=004$ in (E), and $\mathbf{g}=140$ in (F). (G-I) WBDF images of a third location / site with three different diffraction vectors: $\mathbf{g}=130$ in $(\mathbf{G}), \mathbf{g}=041$ in $(\mathbf{H})$, and $\mathbf{g}=211$ in (I).

A subgrain boundary consisting of (001)[100] dislocations was observed during the TEM observation of sample 448 (Figure 8). In Figure 8, the number of terminating thickness fringes for each WBDF image is +1 in Figure $8 \mathrm{~A}(\mathbf{g}=130), 0$ in Figure $8 \mathrm{~B}(\mathbf{g}=041)$, and +2 in Figure $8 \mathrm{C}(\mathbf{g}=211)$; thus, the Burgers vector of this dislocation is [100]. The dislocations consisting of this subgrain boundary are parallel to the [010] axes; therefore, the slip system of these dislocations can be defined as (001)[100]. This TEM observation coincides well with the results of the EBSD Mapping across the subgrain boundary (Figure 3A).
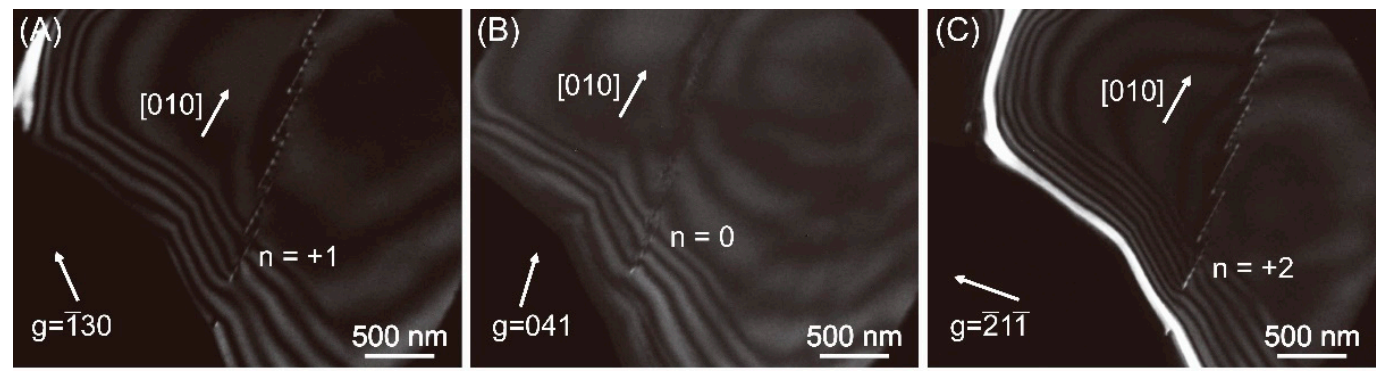

Figure 8. Weak-beam dark-field images showing subgrain boundary of olivine in sample 448. The diffraction vectors for each image are noted as $\mathbf{g}$. The white arrow and $\mathrm{n}$ value indicate the number of the terminating thickness fringes for each image. (A-C) WBDF images of the same location with three different diffraction vectors: $\mathbf{g}=130$ in $(\mathbf{A}), \mathbf{g}=041$ in (B), and $\mathbf{g}=211$, in $(\mathbf{C})$. 


\section{Discussion}

\subsection{Dominant Slip System and Deformation Conditions of Olivine}

The dominant slip system identified from the olivine subgrain boundaries is (001)[100] (Figure 3). Free dislocations in olivine showed dominant (010)[100] slip systems (Table 1). In this section, we will discuss deformation conditions leading to formation of subgrain boundaries and free dislocations in olivine grains from Åheim peridotites. Subgrain boundaries in olivine from Åheim amphibole peridotites, which consist of (001)[100] dislocations, were dominant for both samples 447 and 448 (Figures 3 and 8, Supplementary Table S2). The (001)[100] slip system has been identified from the olivine subgrain boundaries in Many other natural peridotites $[21,61,62,65]$. Previous experimental studies showed that the Etype LPO of olivine, i.e., the activation of the (001)[100] slip system, was obtained under conditions of moderate water content $[3,11,20,73]$. The Åheim amphibole peridotites have undergone multiple stages of aqueous fluid infiltration during the Late Caledonian uplift [55] or subsequent exhumation after orogenic collapse. In a previous study of the Åheim amphibole peridotites, it was reported that the average water content of olivine was $370 \pm 50 \mathrm{ppm} \mathrm{H} / \mathrm{Si}$, and numerous dislocations were observed in the olivine [41]. Thus, the dominant (001)[100] slip system identified from the olivine subgrain boundaries is considered to have been formed by deformation under moderate water content conditions during the exhumation process.

Free dislocations observed in the olivine in both samples 447 and 448 displayed dominant (010)[100] slip systems with minor slip systems of (010)[001] and (001)[100] (Figures 6 and 7; Table 1). Classical studies of olivine slip systems have proposed the (010)[100] slip system as one of the easiest slip systems of olivine [74,75]. In previous experimental studies, the A-type LPO of olivine, that is, the activation of the (010)[100] slip system, was observed under low-stress conditions $[3,10]$. In an active exhuming shear zone, the flow stress increases and the temperature decreases [76]. Therefore, free dislocations in the (010)[100] slip systems can be remnants of the initial slip system at high temperatures. It has been proposed that the A-type olivine LPO, as seen in Åheim amphibole peridotite, is the original Mantle fabric [41]. Therefore, sample 448 showing A-type LPO of olivine could have (010)[100] dislocations that could be remnant dislocations in the initial Mantle rock. Alternatively, the existence of free dislocations within the (010)[100] slip system in olivine May be the result of low stress deformation at the very end of exhumation, when high differential stresses were dissipated.

\subsection{LPO Development of Tremolite}

The LPO of tremolite in the tremolite-rich layer of sample 443 is similar to that of the type-III LPO of amphibole [26] (Figure 4D), and the misorientation axes of tremolite are clustered along the [010] and [001] directions (Figure 4E). In this section, the mechanism of tremolite LPO development in the tremolite-rich layer of sample 443 is discussed. The misorientation axes of tremolite, concentrated in the [010] direction (Figure 4E), can be interpreted as the activation of the (100)[001] or (001)[100] dislocation slip system in tremolite [60]. Among these two slip systems, the (100)[001] slip system is compatible with the observed LPO of tremolite, the [001] axes of tremolite aligned subparallel to the lineation, and [100] axes aligned subnormal to the foliation (Figure 4D). The observed LPO and the misorientation axes of tremolite in the tremolite-rich layer of sample 443 suggest that the (100)[001] slip system of tremolite was activated during deformation and influenced tremolite LPO development. In addition, Many tremolite grains have relatively high GOS values (Figure $4 \mathrm{C}$ ), which could be evidence of abundant intracrystalline misorientation inside the tremolite grains. Furthermore, KAM Maps and GROD Maps showed evidence of intracrystalline plasticity and well-developed subgrain boundaries inside tremolite grains (Figure 5), which support the activation of dislocation creep in the tremolite. The observed subgrain boundaries were free from cracks or fractures (Figure 5), indicating that these subgrain boundaries resulted from intracrystalline plasticity. 
The misorientation axes of tremolite also showed minute concentration along the [001] axis (Figure 4E). The misorientation axes clustered along the [001] axis of amphibole were previously reported in naturally deformed amphiboles from various other localities [29,30,77]. The misorientation axes clustered along the [001] axis can be interpreted as the activation of the (010)[100] or (100)[010] dislocation slip systems [58]. The (100)[010] slip system has not been reported as an easy slip system for amphiboles [33,34,78-80]. The (010)[100] slip system is not compatible with the LPO of tremolite, which shows that the $\{010\}$ poles of tremolite form a girdle distribution along the foliation and the [100] axes align subnormal to the foliation (Figure 4D). It has been suggested that preferential microfracturing along planes, including the [001] crystallographic axis together with small rigid body rotations, might explain the apparent intracrystalline misorientations in amphibole around the [001] rotation axis [30]. Tremolites in sample 443 also display abundant fractures and microfractures (Figure 2E,F). Therefore, rigid body rotation along these fracture planes might have caused the misorientation axes of tremolite to cluster along the [001] axis. The possible deformation stage of amphibole from which the LPO of tremolite and the misorientation axis have been developed are discussed below (Section 5.3).

\subsection{Microstructural Evolution of the Aheim Amphibole Peridotite}

The results of detailed microstructural analysis of the Aheim amphibole peridotites are summarized in Table 2. In this section, the evolution of the microstructure of olivine and amphibole in the Åheim amphibole peridotites will be discussed. The olivine coarse grains from Åheim peridotites showed A-type olivine LPO ((010)[100]), which corresponds to the initial stage of deformation [41]. During the exhumation process and associated retrogression, fluid infiltration triggered retrogression in the amphibole peridotite stability field and recrystallization of olivine $[40,55]$. These recrystallized small olivine grains were deformed under water-rich and/or high-stress conditions in the subsequent stage of deformation in amphibolite facies [40,51,81], resulting in the B-type LPO of olivine $((010)[001])[3,10,41]$. The SPO of amphibole is well Matched with that of olivine grains (Figures 2E and 4A), and the olivine grains in the tremolite-rich layer exhibit a B-type LPO of olivine [41]. Therefore, the LPO of amphibole could have been formed simultaneously with the B-type LPO of olivine.

Table 2. Summary of the microstructural analysis of olivine.

\begin{tabular}{|c|c|c|c|c|}
\hline Sample & $\begin{array}{l}\text { Dominant Slip } \\
\text { Systems of Olivine } \\
\text { Using Subgrain } \\
\text { Boundary }{ }^{1}\end{array}$ & $\begin{array}{l}\text { Dominant Slip } \\
\text { Systems of Olivine } \\
\text { Using Free } \\
\text { Dislocations }^{2}\end{array}$ & LPO of Olivine ${ }^{3}$ & $\begin{array}{l}\text { Inferred Dominant } \\
\text { Slip System of } \\
\text { Olivine from the LPO }\end{array}$ \\
\hline 447 fine+coarse & (001)[100] & (010)[100] & B-type & $(010)[001]$ \\
\hline 448 fine & (001)[100] & (010)[100] & B-type & (010)[001] \\
\hline 448 coarse & (001)[100] & (010)[100] & A-type & (010)[100] \\
\hline
\end{tabular}

${ }^{1}$ by EBSD Mapping; ${ }^{2}$ by TEM analysis; ${ }^{3}$ Lattice preferred orientation (LPO) of olivine [41].

Regardless of the LPOs of olivine, the dominant slip systems of the subgrain boundaries and the free dislocations obtained from the two samples are identical (Table 2); the dominant slip system of the subgrain boundaries is (001)[100] (Figure 3B, Table 2, and Supplementary Table S2) and that of the free dislocations is (010)[100] (Table 1). Thus, the dominant slip systems of olivine dislocations (free dislocations and subgrain boundaries) do not correlate with the inferred dominant slip system of olivine from the A- and B-type LPO of olivine observed in the Åheim amphibole peridotite (Table 2). The olivine fabric transition from the A- to B-type LPO of olivine seems to have been completed before the formation of olivine subgrain boundaries and free dislocations. Subgrain boundaries and free dislocations in olivine might have formed later during the following deformation stage, after the fabric transition from A- to B-type was completed. 
The subgrain boundaries in olivine observed from the Åheim amphibole peridotites (Figures 2, 4 and 7) May represent a secondary stage of deformation after the deformation of samples during amphibolite facies. As discussed above, one possible mechanism of subgrain boundary generation is deformation under moderate water content conditions induced by fluid infiltration $[3,11,20,73]$. The samples were deformed under the same conditions during the exhumation stage, and as a result, an identical slip system was activated when the olivine subgrain boundaries were formed. However, the formation of subgrain boundaries and subsequent dynamic recrystallization did not change the olivine fabric from the previous stage deformation [82]. Owing to the low strain, the second-stage deformation could not renew the olivine fabric but instead inherited the original olivine fabric with weakened fabric strength [83].

As free dislocations form more easily than LPO and subgrain boundaries [21,84], the free dislocations observed in the olivine can be related to the final stage of the deformation. As discussed in the previous section, the free dislocations with the (010)[100] slip system in olivine are interpreted as a result of low-stress deformation $[3,10,85]$ during the exhumation process. The relatively low dislocation density observed in olivine coincides with the low stress deformation [86].

The dominant slip systems of olivine determined from the subgrain boundaries and free dislocations of olivine do not coincide with B-type LPO of olivine (Table 2). There is a possibility that the dislocation microstructures of olivine were totally reset after a final deformation. The other possibility is an activation of grain-size sensitive creep [15-17,87], which is supported by the recrystallized small olivine grains [41].

\section{Conclusions}

The microstructure of the three representative amphibole peridotite samples from Åheim, Norway, revealed evidence of multiple stages of deformation during the Scandian Orogeny and its subsequent exhumation process. The slip systems of olivine identified from the LPOs, subgrain boundaries, and free dislocations represent different deformation conditions and stages. The LPOs of olivine were A-type for the coarse grains and B-type for the fine grains. The dominant slip systems of olivine inferred from the LPOs of olivine were (010)[100] for A-type LPO and (010)[001] for B-type LPO. The slip systems of olivine determined from the subgrain boundaries, which were identified by EBSD Mapping and TEM observation, are predominantly (001)[100], which is interpreted to be related to the deformation under conditions of moderate water content. On the other hand, TEM observation of the free dislocations of olivine revealed that the dominant slip system is (010)[100] for both the samples with A- and B-type LPO, which can result from the deformation under low-stress conditions. Thus, the dominant slip systems of olivine inferred from the LPOs of olivine, subgrain boundaries, and free dislocations do not coincide with one another. The subgrain boundaries and free dislocations in the olivines are considered to have formed during the final deformation stage of the exhumation process after the LPOs of olivine were formed.

Some of the Åheim amphibole peridotites showed a localized tremolite-rich layer. EBSD Mapping of tremolite revealed evidence of tremolite deformation by dislocation creep. Type-III LPO of amphibole, which was observed from tremolite in the localized tremolite-rich layer, is interpreted to have been formed by the activation of the (100)[001] slip system in tremolite.

Supplementary Materials: The following are available online at https:/ / www.mdpi.com/article / 10.3390/min11091018/s1, Figure S1: The examples of minor slip systems of the olivine determined from the subgrain boundaries in olivines of samples 447 and 448, Table S1: Modal composition of the studied samples, Table S2: Olivine slip system determined by EBSD Mapping along olivine subgrain boundaries, Table S3: Summary of olivine slip systems determined from the thickness fringe method in Figures 6-8. 
Author Contributions: Conceptualization, H.J.; Methodology, J.-i.A. and H.J.; Software, S.J. and T.Y.; Validation, S.J., T.Y., J.-i.A. and H.J.; Formal Analysis, S.J.; Investigation, S.J. and T.Y.; Resources, S.J. and T.Y.; Data Curation, S.J. and J.-i.A.; Writing-Original Draft Preparation, S.J.; WritingReview \& Editing, S.J., T.Y., J.-i.A. and H.J.; Visualization, S.J.; Supervision, H.J.; Project Administration, H.J.; Funding Acquisition, H.J. All authors have read and agreed to the published version of the Manuscript.

Funding: This research was funded by the Mid-career Research Program through National Research Foundation of Korea (NRF: 2020R1A2C2003765) to H.J.

Data Availability Statement: Not applicable.

Acknowledgments: The authors are grateful to Håkon Austrheim for his help in the field and to three reviewers and editor Jacques Précigout for constructive comments and corrections.

Conflicts of Interest: The authors declare no conflict of interest.

\section{References}

1. Karato, S. Deformation of Earth Materials: An Introduction to the Rheology of Solid Earth; Cambridge University Press: New York, NY, USA, 2008.

2. Mainprice, D.; Nicolas, A. Development of shape and lattice preferred orientations: Application to the seismic anisotropy of the lower crust. J. Struct. Geol. 1989, 11, 175-189. [CrossRef]

3. Jung, H.; Katayama, I.; Jiang, Z.; Hiraga, T.; Karato, S. Effect of water and stress on the lattice-preferred orientation of olivine. Tectonophysics 2006, 421,1-22. [CrossRef]

4. Lister, G.S.; Paterson, M.S.; Hobbs, B.E. The simulation of fabric development in plastic deformation and its application to quartzite: The model. Tectonophysics 1978, 45, 107-158. [CrossRef]

5. $\quad$ van Houtte, P.; Wagner, F. Development of Textures by Slip and Twinning, in Preferred Orientation in Deformed Metals and Rocks: An Introduction to Modern Texture Analysis; Academic Press: New York, NY, USA, 1985.

6. Molinari, A.; Canova, G.R.; Ahzi, S. A self-consistent approach of the large deformation polycrystal viscoplasticity. Acta Metall. 1987, 35, 2983-2994. [CrossRef]

7. Winger, L.A.; Bradt, R.C.; Hoke, J.H. Transformational Superplasticity of $\mathrm{Bi}_{2} \mathrm{WO}_{6}$ and $\mathrm{Bi}_{2} \mathrm{MoO}_{6}$. J. Am. Ceram. Soc. 1980, 63, 291-294. [CrossRef]

8. Ben Ismail, W.; Mainprice, D. An olivine fabric database: An overview of upper Mantle fabrics and seismic anisotropy. Tectonophysics 1998, 296, 145-157. [CrossRef]

9. Nicolas, A.; Christensen, N.I. Formation of anisotropy in upper Mantle peridotites: A review. Geodyn. Ser. 1987, 16, 111-123. [CrossRef]

10. Jung, H.; Karato, S. Water-Induced Fabric Transitions in Olivine. Science 2001, 293, 1460-1463. [CrossRef]

11. Katayama, I.; Jung, H.; Karato, S. New type of olivine fabric from deformation experiments at modest water content and low stress. Geology 2004, 32, 1045-1048. [CrossRef]

12. Ohuchi, T.; Kawazoe, T.; Nishihara, Y.; Nishiyama, N.; Irifune, T. High pressure and temperature fabric transitions in olivine and variations in upper Mantle seismic anisotropy. Earth Planet. Sci. Lett. 2011, 304, 55-63. [CrossRef]

13. Karato, S.; Jung, H.; Katayama, I.; Skemer, P. Geodynamic Significance of Seismic Anisotropy of the Upper Mantle: New Insights from Laboratory Studies. Annu. Rev. Earth Planet. Sci. 2008, 36, 59-95. [CrossRef]

14. Jung, H. Crystal preferred orientations of olivine, orthopyroxene, serpentine, chlorite, and amphibole, and implications for seismic anisotropy in subduction zones: A review. Geosci. J. 2017, 21, 985-1011. [CrossRef]

15. Precigout, J.; Stunitz, H. Evidence of phase nucleation during olivine diffusion creep: A new perspective for Mantle strain localisation. Earth Planet. Sci. Lett. 2016, 455, 94-105. [CrossRef]

16. Precigout, J.; Hirth, G. B-type olivine fabric induced by grain boundary sliding. Earth Planet. Sci. Lett. 2014, 395, 231-240. [CrossRef]

17. Sundberg, M.; Cooper, R.F. Crystallographic preferred orientation produced by diffusional creep of harzburgite: Effects of chemical interactions among phases during plastic flow. J. Geophys. Res. -Solid Earth 2008, 113, 16. [CrossRef]

18. Demouchy, S.; Mussi, A.; Barou, F.; Tommasi, A.; Cordier, P. Viscoplasticity of polycrystalline olivine experimentally deformed at high pressure and 900 degrees C. Tectonophysics 2014, 623, 123-135. [CrossRef]

19. Raterron, P.; Amiguet, E.; Chen, J.H.; Li, L.; Cordier, P. Experimental deformation of olivine single crystals at Mantle pressures and temperatures. Phys. Earth Planet. Inter. 2009, 172, 74-83. [CrossRef]

20. Wang, L.; Miyajima, N.; Kawazoe, T.; Katsura, T. Activation of 100 (001) slip system by water incorporation in olivine and the cause of seismic anisotropy decrease with depth in the asthenosphere. Am. Miner. 2019, 104, 47-52. [CrossRef]

21. Yamamoto, T.; Ando, J.; Tomioka, N.; Kobayashi, T. Deformation history of Pinatubo peridotite xenoliths: Constraints from microstructural observation and determination of olivine slip systems. Phys. Chem. Miner. 2017, 44, 247-262. [CrossRef]

22. Wang, C.G.; Liang, Y.; Xu, W.L. Formation of Amphibole-Bearing Peridotite and Amphibole-Bearing Pyroxenite Through Hydrous Melt-Peridotite Reaction and in Situ Crystallization: An Experimental Study. J. Geophys. Res. Solid Earth 2021, 126, 22. [CrossRef] 
23. Mandler, B.; Grove, T.L. Controls on the stability and composition of amphibole in the Earth's Mantle. Contrib. Mineral. Petrol. 2016, 171, 20. [CrossRef]

24. Green, D.H.; Hibberson, W.O.; Rosenthal, A.; Kovacs, I.; Yaxley, G.M.; Falloon, T.J.; Brink, F. Experimental Study of the Influence of Water on Melting and Phase Assemblages in the Upper Mantle. J. Petrol. 2014, 55, 2067-2096. [CrossRef]

25. Fumagalli, P.; Zanchetta, S.; Poli, S. Alkali in phlogopite and amphibole and their effects on phase relations in metasomatized peridotites: A high-pressure study. Contrib. Mineral. Petrol. 2009, 158, 723-737. [CrossRef]

26. Ko, B.; Jung, H. Crystal preferred orientation of an amphibole experimentally deformed by simple shear. Nat. Commun. 2015, 6, 10. [CrossRef] [PubMed]

27. Cao, S.Y.; Liu, J.L.; Leiss, B. Orientation-related deformation mechanisms of naturally deformed amphibole in amphibolite mylonites from the Diancang Shan, SW Yunnan, China. J. Struct. Geol. 2010, 32, 606-622. [CrossRef]

28. Imon, R.; Okudaira, T.; Kanagawa, K. Development of shape- and lattice-preferred orientations of amphibole grains during initial cataclastic deformation and subsequent deformation by dissolution-precipitation creep in amphibolites from the Ryoke metamorphic belt, SW Japan. J. Struct. Geol. 2004, 26, 793-805. [CrossRef]

29. Aspiroz, M.D.; Lloyd, G.E.; Fernandez, C. Development of lattice preferred orientation in clinoamphiboles deformed under low-pressure metamorphic conditions. A SEM/EBSD study of metabasites from the Aracena metamorphic belt (SW Spain). J. Struct. Geol. 2007, 29, 629-645. [CrossRef]

30. Soret, M.; Agard, P.; Ildefonse, B.; Dubacq, B.; Prigent, C.; Rosenberg, C. Deformation mechanisms in Mafic amphibolites and granulites: Record from the Semail metamorphic sole during subduction infancy. Solid Earth 2019, 10, 1733-1755. [CrossRef]

31. Kim, J.; Jung, H. New Crystal Preferred Orientation of Amphibole Experimentally Found in Simple Shear. Geophys. Res. Lett. 2019, 46, 12996-13005. [CrossRef]

32. Almqvist, B.S.G.; Mainprice, D. Seismic properties and anisotropy of the continental crust: Predictions based on mineral texture and rock microstructure. Rev. Geophys. 2017, 55, 367-433. [CrossRef]

33. Skrotzki, W. Defect structure and deformation mechanisms in naturally deformed hornblende. Phys. Status Solidi A-Appl. Res. 1992, 131, 605-624. [CrossRef]

34. Dollinger, G.; Blacic, J.D. Deformation mechanisms in experimentally and naturally deformed amphiboles. Earth Planet. Sci. Lett. 1975, 26, 409-416. [CrossRef]

35. Rooney, T.P.; Riecker, R.E.; Ross, M. Deformation twins in hornblende. Science 1970, 169, 173-175. [CrossRef]

36. Tatham, D.J.; Lloyd, G.E.; Butler, R.W.H.; Casey, M. Amphibole and lower crustal seismic properties. Earth Planet. Sci. Lett. 2008, 267, 118-128. [CrossRef]

37. Getsinger, A.J.; Hirth, G.; Stunitz, H.; Goergen, E.T. Influence of water on rheology and strain localization in the lower continental crust. Geochem. Geophys. Geosyst. 2013, 14, 2247-2264. [CrossRef]

38. Getsinger, A.J.; Hirth, G. Amphibole fabric formation during diffusion creep and the rheology of shear zones. Geology 2014, 42, 535-538. [CrossRef]

39. Wang, X.; Zhang, J.; Tommasi, A.; Jing, Z.; Yuan, M. Microstructure and seismic properties of amphibole-rich rocks from the deep crust in southern Tibet. Tectonophysics 2021, 811, 228869. [CrossRef]

40. Brueckner, H.K.; Carswell, D.A.; Griffin, W.L.; Medaris, L.G.; Van Roermund, H.L.M.; Cuthbert, S.J. The Mantle and crustal evolution of two garnet peridotite suites from the Western Gneiss Region, Norwegian Caledonides: An isotopic investigation. Lithos 2010, 117, 1-19. [CrossRef]

41. Jung, S.; Jung, H.; Austrheim, H. Microstructural Evolution of Amphibole Peridotites in Åheim, Norway, and the Implications for Seismic Anisotropy in the Mantle Wedge. Minerals 2020, 10, 345. [CrossRef]

42. Austrheim, H. Fluid and deformation induced metamorphic processes around Moho beneath continent collision zones: Examples from the exposed root zone of the Caledonian mountain belt, W-Norway. Tectonophysics 2013, 609, 620-635. [CrossRef]

43. Austrheim, H.; Corfu, F.; Bryhni, I.; Andersen, T.B. The Proterozoic Hustad igneous complex: A low strain enclave with a key to the history of the Western Gneiss Region of Norway. Precambrian Res. 2003, 120, 149-175. [CrossRef]

44. Hacker, B.R.; Andersen, T.B.; Johnston, S.; Kylander-Clark, A.R.C.; Peterman, E.M.; Walsh, E.O.; Young, D. High-temperature deformation during continental-margin subduction \& exhumation: The ultrahigh-pressure Western Gneiss Region of Norway. Tectonophysics 2010, 480, 149. [CrossRef]

45. Soper, N.J.; Strachan, R.A.; Holdsworth, R.E.; Gayer, R.A.; Greiling, R.O. Sinistral transpression and the closure of Iapetus. J. Geol. Soc. 1992, 149, 871-880. [CrossRef]

46. Gee, D.G. Tectonic model for central part of Scandinavian Caledonides. Am. J. Sci. 1975, A275, 468-515.

47. Roberts, D. The Scandinavian Caledonides: Event chronology, palaeogeographic settings and likely, modern analogues. Tectonophysics 2003, 365, 283-299. [CrossRef]

48. Dobrzhinetskaya, L.F.; Eide, E.A.; Larsen, R.B.; Sturt, B.A.; Tronnes, R.G.; Smith, D.C.; Taylor, W.R.; Posukhova, T.V. Microdiamond in high-grade metamorhic rocks of the Western Gneiss Region, Norway. Geology 1995, 23, 597-600. [CrossRef]

49. Vrijmoed, J.C.; Van Roermund, H.L.M.; Davies, G.R. Evidence for diamond-grade ultra-high pressure metamorphism and fluid interaction in the Svartberget Fe-Ti garnet peridotite-websterite body, Western Gneiss Region, Norway. Mineral. Petrol. 2006, 88, 381-405. [CrossRef]

50. Root, D.B.; Hacker, B.R.; Gans, P.B.; Ducea, M.N.; Eide, E.A.; Mosenfelder, J.L. Discrete ultrahigh-pressure domains in the Western Gneiss Region, Norway: Implications for formation and exhumation. J. Metamorph. Geol. 2005, 23, 45-61. [CrossRef] 
51. Carswell, D.A. The metamorphic evolution of Mg-Cr type Norwegian garnet peridotites. Lithos 1986, 19, 279-297. [CrossRef]

52. Wang, Q.; Xia, Q.K.; O’Reilly, S.Y.; Griffin, W.L.; Beyer, E.E.; Brueckner, H.K. Pressure- and stress-induced fabric transition in olivine from peridotites in the Western Gneiss Region (Norway): Implications for Mantle seismic anisotropy. J. Metamorph. Geol. 2013, 31, 93-111. [CrossRef]

53. Cordellier, F.; Boudier, F.; Boullier, A.M. Structural study of the Almklovdalen peridotite Massif (southern-Norway). Tectonophysics 1981, 77, 257-281. [CrossRef]

54. Jamtveit, B.; Carswell, D.A.; Mearns, E.W. Chronology of the high-pressure metamorphism of Norwegian garnet peridotites pyroxenites. J. Metamorph. Geol. 1991, 9, 125-139. [CrossRef]

55. Kostenko, O.; Jamtveit, B.; Austrheim, H.; Pollok, K.; Putnis, C. The mechanism of fluid infiltration in peridotites at Almklovdalen, western Norway. Geofluids 2002, 2, 203-215. [CrossRef]

56. Kylander-Clark, A.R.C.; Hacker, B.R.; Mattinson, J.M. Slow exhumation of UHP terranes: Titanite and rutile ages of the Western Gneiss Region, Norway. Earth Planet. Sci. Lett. 2008, 272, 531-540. [CrossRef]

57. Panozzo, R. Two-dimensional strain from the orientation of lines in a plane. J. Struct. Geol. 1984, 6, 215-221. [CrossRef]

58. Lloyd, G.E.; Farmer, A.B.; Mainprice, D. Misorientation analysis and the formation and orientation of subgrain and grain boundaries. Tectonophysics 1997, 279, 55-78. [CrossRef]

59. Prior, D.J.; Boyle, A.P.; Brenker, F.; Cheadle, M.C.; Day, A.; Lopez, G.; Peruzzo, L.; Potts, G.J.; Reddy, S.; Spiess, R.; et al. The application of electron backscatter diffraction and orientation contrast imaging in the SEM to textural problems in rocks. Am. Miner. 1999, 84, 1741-1759. [CrossRef]

60. Wheeler, J.; Prior, D.J.; Jiang, Z.; Spiess, R.; Trimby, P.W. The petrological significance of misorientations between grains. Contrib. Mineral. Petrol. 2001, 141, 109-124. [CrossRef]

61. Kaczmarek, M.A.; Reddy, S.M. Mantle deformation during rifting: Constraints from quantitative microstructural analysis of olivine from the East African Rift (Marsabit, Kenya). Tectonophysics 2013, 608, 1122-1137. [CrossRef]

62. Katayama, I.; Michibayashi, K.; Terao, R.; Ando, J.; Komiya, T. Water content of the Mantle xenoliths from Kimberley and implications for explaining textural variations in cratonic roots. Geol. J. 2011, 46, 173-182. [CrossRef]

63. Palasse, L.N.; Vissers, R.L.M.; Paulssen, H.; Basu, A.R.; Drury, M.R. Microstructural and seismic properties of the upper Mantle underneath a rifted continental terrane (Baja California): An example of sub-crustal mechanical asthenosphere? Earth Planet. Sci. Lett. 2012, 345, 60-71. [CrossRef]

64. Kumamoto, K.M.; Warren, J.M.; Hansen, L.N. Evolution of the Josephine Peridotite Shear Zones: 2. Influences on Olivine Cpo Evolution. J. Geophys. Res. Solid Earth 2019, 124, 12763-12781. [CrossRef]

65. Cao, Y.; Jung, H.; Song, S.G.; Park, M.; Jung, S.; Lee, J. Plastic Deformation and Seismic Properties in Fore-arc Mantles: A Petrofabric Analysis of the Yushigou Harzburgites, North Qilian Suture Zone, NW China. J. Petrol. 2015, 56, 1897-1943. [CrossRef]

66. Precigout, J.; Prigent, C.; Palasse, L.; Pochon, A. Water pumping in Mantle shear zones. Nat. Commun. 2017, 8, 10. [CrossRef] [PubMed]

67. Wright, S.I. A review of automated orientation imaging microscopy (OIM). J. Comput. -Assist. Microsc. 1993, 5, $207-221$.

68. Brewer, L.N.; Othon, M.A.; Young, L.M.; Angeliu, T.M. Misorientation Mapping for visualization of plastic strain via electron back-scattered diffraction. Microsc. Microanal. 2006, 12, 85-91. [CrossRef]

69. Wright, S.I.; Nowell, M.M.; Field, D.P. A Review of Strain Analysis Using Electron Backscatter Diffraction. Microsc. Microanal. 2011, 17, 316-329. [CrossRef]

70. Ando, J.; Fujino, K.; Takeshita, T. Dislocation microstructures in naturally deformed silicate garnets. Phys. Earth Planet. Inter. 1993, 80, 105-116. [CrossRef]

71. Ishida, Y.; Ishida, H.; Kohra, K.; Ichinose, H. Determination of the Burgers vector of a dislocation by weak-beam imaging in a HVEM. Philos. Mag. A-Phys. Condens. Matter Struct. Defect Mech. Prop. 1980, 42, 453-462. [CrossRef]

72. Miyajima, N.; Walte, N. Burgers vector determination in deformed perovskite and post-perovskite of CaIrO3 using thickness fringes in weak-beam dark-field images. Ultramicroscopy 2009, 109, 683-692. [CrossRef]

73. Tielke, J.; Mecklenburgh, J.; Mariani, E.; Wheeler, J. The Influence of Water on the Strength of Olivine Dislocation Slip Systems. J. Geophys. Res. -Solid Earth 2019, 124, 6542-6559. [CrossRef]

74. Carter, N.L.; Lallemant, H.G.A. High temperature flow of dunite and peridotite. Geol. Soc. Am. Bull. 1970, 81, $2181-2202$. [CrossRef]

75. Phakey, P.; Dollinger, G.; Christie, J. Transmission electron microscopy of experimentally deformed olivine crystals. Flow Fract. Rocks 1972, 117-138. [CrossRef]

76. Behr, W.M.; Platt, J.P. A naturally constrained stress profile through the middle crust in an extensional terrane. Earth Planet. Sci. Lett. 2011, 303, 181-192. [CrossRef]

77. Elyaszadeh, R.; Prior, D.J.; Sarkarinejad, K.; Mansouri, H. Different slip systems controlling crystallographic preferred orientation and intracrystalline deformation of amphibole in mylonites from the Neyriz Mantle diapir, Iran. J. Struct. Geol. 2018, 107, 38-52. [CrossRef]

78. Rooney, T.P.; Riecker, R.E.; Gavasci, A.T. Hornblende deformation features. Geology 1975, 3, 364-366. [CrossRef]

79. Biermann, C.; Vanroermund, H.L.M. Defect structures in naturally deformed clinoamphiboles-A TEM study. Tectonophysics 1983, 95, 267-278. [CrossRef]

80. Morrison-Smith, D.J. Transmission electron microscopy of experimentally deformed hornblende. Am. Miner. 1976, 61, 272-280. 
81. Lapen, T.J.; Medaris, L.G.; Beard, B.L.; Johnson, C.M. The Sandvik peridotite, Gurskoy, Norway: Three billion years of Mantle evolution in the Baltica lithosphere. Lithos 2009, 109, 145-154. [CrossRef]

82. Boneh, Y.; Skemer, P. The effect of deformation history on the evolution of olivine CPO. Earth Planet. Sci. Lett. 2014, 406, 213-222. [CrossRef]

83. Skemer, P.; Karato, S.I. Sheared lherzolite xenoliths revisited. J. Geophys. Res. -Solid Earth 2008, 113, 14. [CrossRef]

84. Matsumoto, K.; Toriumi, M. Mechanical states of the upper Mantle under the island arc as inferred from the microstructures of peridotite nodules. In Rheology of Solids and of the Earth; Karato, S., Toriumi, M., Eds.; Oxford Scientific Publications: New York, NY, USA, 1989; pp. 374-392.

85. Goetze, C. The mechanisms of creep in olivine. Philos. Trans. R. Soc. A-Math. Phys. Eng. Sci. 1978, 288, 99-119. [CrossRef]

86. Toriumi, M. Relation between dislocation density and subgrain size of naturally deformed olivine in peridotites. Contrib. Mineral. Petrol. 1979, 68, 181-186. [CrossRef]

87. Cao, Y.; Jung, H.; Song, S.G. Olivine fabrics and tectonic evolution of fore-arc Mantles: A natural perspective from the Songshugou dunite and harzburgite in the Qinling orogenic belt, central China. Geochem. Geophys. Geosyst. 2017, 18, 907-934. [CrossRef] 